\title{
A Taylor Rule for Public Debt
}

Costas Azariadis

Public debt is an important source of liquidity in economies facing shortages of private credit. It is also a bubble whose current price depends on expectations of what it will buy at future dates. In this article, the author studies how the government must balance the provision of sufficient liquidity against the risk of adverse expectations regarding future debt prices when private liquidity has dried up. The socially optimal balance is captured in a Taylor-like rule that sets a target for real public debt and manages expectations by overreacting to deviations from the target value. Overreaction takes the form of manipulating budget surpluses to absorb excess debt or reverse liquidity shortages. A budget surplus (deficit) is equivalent to an income tax (subsidy) on investors that restrains (raises) their demand for liquid assets. (JEL H60, E52)

Federal Reserve Bank of St. Louis Review, Third Quarter 2016, 98(3), pp. 227-38. http://dx.doi.org/10.20955/r.2016.227-238

\section{ISSUES AND IDEAS}

Classical economists such as Thornton (1802) and Bagehot (1873) understood that one important function of public sector liabilities is the provision of liquidity in times of financial distress. ${ }^{1}$ Early research stressed the role of central banks in averting financial panics or catastrophic contractions in private credit driven by pessimistic expectations. Public debt can also help in (i) low-collateral economies with a built-in shortage of liquid assets such as those analyzed in Kiyotaki and Moore (1997) and Bernanke and Gertler (1989) and (ii) environments with weak enforcement such as those in Bulow and Rogoff (1989) and Hellwig and Lorenzoni (2009). The downside of public debt is its fragile or bubble nature, which makes it sensitive to speculative attacks and financial panics. As shown in an extensive literature starting with Tirole (1985) and ending with Kocherlakota (2009), bubbles are assets that add nothing to national income and are socially useful only when investors believe they will maintain their value in the future. Under rational expectations or perfect foresight, bubbles are unstable

\footnotetext{
Costas Azariadis is the Edward Mallinckrodt Distinguished Professor in Arts and Sciences in the Department of Economics at Washington University in St. Louis and a research fellow at the Federal Reserve Bank of St. Louis. The author thanks David Andolfatto for detailed comments and Minhyeon Jeong for valuable research assistance.

(c) 2016, Federal Reserve Bank of St. Louis. The views expressed in this article are those of the author(s) and do not necessarily reflect the views of the Federal Reserve System, the Board of Governors, or the regional Federal Reserve Banks. Articles may be reprinted, reproduced, published, distributed, displayed, and transmitted in their entirety if copyright notice, author name(s), and full citation are included. Abstracts, synopses, and other derivative works may be made only with prior written permission of the Federal Reserve Bank of St. Louis.
} 
equilibria that can quickly unravel if expectations turn pessimistic in the slightest degree. Keeping bubbles alive requires expectations to be almost permanently optimistic. Thoughtful fiscal policy must then strike a balance between the provision of sufficient liquidity and the feeding of adverse forecasts about the future value of national debt.

How does the government achieve and maintain this balance? This article addresses this question. The setting is a hypothetical economy with no collateral income and no private credit; nothing of substance will change if we look instead at an environment with modest amounts of collateral in which good outcomes are impossible without some form of government intervention. Suppose now that $B^{*}$ is the socially optimal amount of liquidity that, under ideal conditions, would be provided by private sources. If private debt is substantially or completely illiquid, most or all of the amount $B^{*}$ must come from the sale of public debt to the private sector, with the government imposing a small tax $\tau^{*}$ to pay interest on $B^{*}$.

Investors' expectations of the future value of public debt depend critically on fiscal policy. To reassure investors, the government may commit to raise taxes above $\tau^{*}$ whenever public debt exceeds $B^{*}$ and to lower them below $\tau^{*}$ in the reverse situation. This commitment helps maintain the value of debt near $B^{*}$ by promising investors that an oversupply (undersupply) of debt will be aggressively countered by a primary budget surplus (deficit).

Ideally, fiscal policy should seek to maintain the optimum level of liquidity by absorbing excess liquidity immediately and making up liquidity shortages with equal dispatch. A Taylor rule for public debt will achieve these goals if policy overreacts to deviations of public debt from its socially optimal value. Taxes impose an income effect on investors that works like an automatic stabilizer in this framework. When public debt lurches above its target value, investor incomes are hit with higher taxes, which rein in the demand for liquidity. In the reverse case, taxes shrink, disposable incomes rise, and the demand for public debt expands.

To understand the need for fiscal policy to overreact, suppose that investors demand liquidity to raise future consumption at the expense of current consumption. How should fiscal policy manipulate taxes to raise or lower disposable incomes? Any change in income will typically affect both current and future consumption. Reducing future consumption, or the demand for public debt, by one unit typically requires current taxes to rise by more than one unit and disposable income to fall by a corresponding amount. It is in that sense that policy should be aggressive. Exactly how much overreaction is socially optimal is the main concern of this article.

\section{THE OPTIMUM AMOUNT OF LIQUIDITY}

\section{Private Liquidity with Perfect Financial Markets}

To fix notation, let us look at the possibilities for consumption smoothing in an economy with deterministic individual incomes, populated by two groups of agents indexed by $i=1,2$, each with unit mass. Time is discrete, extends to infinity, and is denoted by $t=0,1,2, \ldots$. Each agent $i$ has preferences given by

$$
\sum_{t=0}^{\infty} \beta^{t} u\left(c_{t}^{i}\right)
$$


with $0<\beta<1$. The aggregate endowment is constant at two units, but its distribution over agents changes deterministically over time. In particular, individual endowments are periodic ${ }^{2}$ - that is,

$$
\left(\omega_{t}^{2}, \omega_{t}^{1}\right)= \begin{cases}(1+\alpha, 1-\alpha), & \text { if } t=0,2, \ldots \\ (1-\alpha, 1+\alpha), & \text { if } t=1,3, \ldots\end{cases}
$$

with $\alpha \in(0,1)$.

In a standard dynamic general equilibrium model with abundant collateral and perfect enforcement of loan contracts, an equilibrium is an infinite sequence $\left(c_{t}^{i}, b_{t}^{i}, q_{t}\right)$ that describes, for each period $t$, the consumption $c_{t}^{i}$ for each agent, their security holdings $b_{t}^{i}$, and the price of loans $q_{t}$ in terms of the consumption good. This sequence satisfies a consumption Euler equation for each person, two budget constraints, and market clearing. These equations are

$$
\begin{gathered}
q_{t} u^{\prime}\left(c_{t}^{i}\right)=\beta u^{\prime}\left(c_{t+1}^{i}\right) \\
c_{t}^{i}+q_{t} b_{t+1}^{i}=\omega_{t}^{i}+b_{t}^{i} \\
b_{t}^{1}+b_{t}^{2}=0 ;\left(b_{0}^{1}, b_{0}^{2}\right) \text { given }
\end{gathered}
$$

for all $(i, t)$, where $q_{t}$ is the price of a one-period private security paying off one unit of consumption at $t+1$, and $b_{t+1}^{i}$ is the number of those securities purchased by household $i$ at time $t$.

This setting of perfect financial markets with full commitment to repay loans has a unique competitive equilibrium with perfect consumption smoothing for every $t=0,1, \ldots$ :

$$
\left(c_{t}^{1}, c_{t}^{2}\right)=\left(c_{1}^{*}, c_{2}^{*}\right)
$$

supported by a bond price

$$
q_{t}=\beta \quad \forall t,
$$

which corresponds to equality between the rate of return on private debt and the rate of time preference. Consumption flows $\left(c_{1}^{*}, c_{2}^{*}\right)$ satisfy household budget constraints, equating the present value of consumption with household wealth. Specifically,

$$
\begin{aligned}
& \frac{c_{1}^{*}}{1-\beta}=\frac{1+\alpha+\beta(1-\alpha)}{1-\beta^{2}}+b_{0}^{1} \\
& \frac{c_{2}^{*}}{1-\beta}=\frac{1-\alpha+\beta(1+\alpha)}{1-\beta^{2}}+b_{0}^{2} .
\end{aligned}
$$

As one might expect, this equilibrium is Pareto optimal and aggregate consumption equals aggregate income-that is, 


$$
c_{1}^{*}+c_{2}^{*}=2
$$

because $b_{0}^{1}+b_{0}^{2}=0$. The allocation of consumption across households depends on the initial distribution of $\left(b_{0}^{1}, b_{0}^{2}\right)$ of financial wealth. A particularly interesting initial distribution is

$$
\left(b_{0}^{1}, b_{0}^{2}\right)=\left(\frac{\alpha}{1+\beta},-\frac{\alpha}{1+\beta}\right),
$$

which gives households with low initial income, $1-\alpha$, a claim against those with high initial income, $1+\alpha$. In this case, the unique equilibrium is symmetric with

$$
c_{1}^{*}=c_{2}^{*}=1
$$

and private debt holdings that alternate between $\alpha /(1+\beta)$ and $-\alpha /(1+\beta)$. Specifically,

$$
\left(b_{t}^{1}, b_{t}^{2}\right)=\left\{\begin{array}{l}
\left(\frac{\alpha}{1+\beta},-\frac{\alpha}{1+\beta}\right) \text { if } t=0,2, \ldots \\
\left(-\frac{\alpha}{1+\beta}, \frac{\alpha}{1+\beta}\right) \text { if } t=1,3, \ldots
\end{array} .\right.
$$

Commitment to repay debts is essential in achieving this allocation of resources. If borrowers have little or no collateralizable income, financial markets will work poorly and households may not be able to receive the amount of liquidity needed to support perfect consumption smoothing. In the following text, I briefly review two types of financial market imperfections and then concentrate on the extreme case of financial distress that occurs when private credit dries up completely.

\section{Private Liquidity with Imperfect Financial Markets}

Before considering public debt, I briefly discuss what could go wrong with private debt in an environment with financial frictions. A particularly useful friction to consider is limited enforceability of loan contracts, which restricts the amount each household can borrow either by the pledgeable collateral owned by that household or by how much the borrower values a good reputation that permits unfettered access to future credit. Kiyotaki and Moore (1997), for example, analyze credit market imperfections by adding to the household problem of the previous subsection a collateral constraint of the form

$$
b_{t}^{i}+\lambda_{t} \omega_{t}^{i} \geq 0
$$

where $\lambda_{t} \in[0,1]$ is an exogenous leverage ratio describing the fraction of a borrower's income that lenders can claim in the event of default.

Kehoe and Levine (1993) propose to make the leverage ratio $\lambda_{t}$ endogenous by connecting access to future credit with the reputation of each borrower. In this setting, enforcement 
works through reputation. Borrowers who default are shut out of credit markets and forced into permanent autarky - they cannot borrow or lend ever again. Solvency is maintained by credit lines that motivate borrowers to repay and continue trading in the credit market instead of default and autarky.

Self-enforcing loans of that type satisfy an incentive constraint of the form

$$
\sum_{s=0}^{\infty} \beta^{s}\left[u\left(c_{t+s}^{i}\right)-u\left(\omega_{t+s}^{i}\right)\right] \geq 0
$$

for each $i$ and $t$. This constraint keeps the value of solvency at or above the value of default for everyone at all times. It holds with equality for rationed borrowers. Alvarez and Jermann (2000) show how to find leverage ratios that connect equation (12) to equation (11).

It is fairly easy to guess what happens in an economy with debt constraints of the type described in equation (11). If the leverage ratio $\lambda_{t}$ is always sufficiently large, the symmetric equilibrium of the previous subsection still goes through. This happens when

$$
\lambda_{t}(1+\alpha) \geq \alpha /(1+\beta)
$$

for all $t \geq 0$ in equation (11), and when

$$
\frac{u(1)}{1-\beta} \geq \frac{u(1+\alpha)+\beta u(1-\alpha)}{1-\beta^{2}}
$$

in equation (12). Adverse collateral shocks will violate equation (13) and reduce the amount of consumption smoothing achieved in equilibrium. As the leverage ratio shrinks in equation (11), equilibrium allocations will approach autarky-that is,

$$
c_{t}^{i} \rightarrow \omega_{t}^{i} \text { as } \lambda_{t} \rightarrow 0 .
$$

The same problem crops up in the Kehoe-Levine economy when condition (14) is violated. When that happens, endogenous leverage ratios $\lambda_{t}$ tend to depend on expectations of future leverage ratios $\left(\lambda_{t+1}, \lambda_{t+2}, \ldots\right)$. If future values of $\lambda$ are small, then the credit market does not help smooth future consumption, which reduces the value of a good reputation to the borrower and makes lenders unwilling to lend now. Pushing this syllogism to the end, autarky turns out to be a socially undesirable but stable equilibrium in which pessimistic expectations of credit panics are self-fulfilling.

More sanguine forecasts of future credit conditions lead to better equilibria, but consumption smoothing will typically be limited by borrowing constraints. One way to avoid catastrophic reductions in private credit is for the central bank to act as a lender of last resort. ${ }^{3}$ Significant reductions in non-collateral credit did actually happen in the last quarter of 2008 and the first quarter of 2009 when the stock of commercial paper in circulation dropped by more than 50 percent. How should the government react when that occurs? 


\section{The Role of Public Debt}

One reason public debt is more tradable than private debt is that the fiscal authority has certain powers of enforcing claims on households that the private sector does not possess. Suppose, in particular, that the government can extract a modest tax

$$
\tau_{t} \leq \bar{\tau}
$$

from every high-income individual and use the proceeds to finance transfers to low-income individuals or to repay those it borrowed from in the past. The government budget constraint is then

$$
\tau_{t}=\left\{\begin{array}{cc}
B_{t}-q_{t} B_{t+1} & \text { if } q_{t}>0 \\
0 & \text { if } q_{t}=0
\end{array},\right.
$$

where $B_{t+1}$ is the real value of public debt issued at $t$ and maturing at $t+1$. Taxes amount to a primary budget surplus that pays interest on existing public debt.

The rest of the economy functions in the way described by equations (3), (4), (5), and (15), except for the budget constraint (4) and the market-clearing condition (5), which now reflect the payment of taxes and the existence of a financial asset (public debt) in positive net supply. These equations become

$$
\begin{gathered}
c_{t}^{i}+q_{t} B_{t+1}^{i}=\omega_{t}^{i}+B_{t}^{i}-\tau_{t}^{i} \text { and } \\
B_{t}^{1}+B_{t}^{2}=B_{t} .
\end{gathered}
$$

Here $B_{t}^{i} \geq 0$ denotes claims on the government and

$$
\tau_{t}^{i}=\left\{\begin{array}{cc}
\tau_{t} & \text { if } \omega_{t}^{i}=1+\alpha \\
0 & \text { otherwise }
\end{array} .\right.
$$

It is a simple matter to verify from the budget constraint (15), from equation (4'), and from the market-clearing condition $\left(5^{\prime}\right)$ that the policy choice

$$
\tau_{t}=\tau^{*}:=\alpha(1-\beta) \quad \forall t
$$

will support a steady-state equilibrium with constant public debt $B^{*}$, bond price $q^{*}$, and constant consumption $c^{*}$ for each $i$, where the high-income person buys the entire stock of public debt from the low-income person, and

$$
\left(B^{*}, q^{*}, c^{*}\right)=(\alpha, \beta, 1)
$$

In other words, the fiscal authority can stand in for the malfunctioning private credit market and provide the optimum amount of liquidity if high-income households expect that 
the price of public debt will remain forever constant at its maximal value $\beta$. To understand the circumstances that justify this level of optimism, we need to delve into the dynamics of public debt and of asset bubbles.

\section{MANAGING BUBBLES}

Can the government raise the odds that markets will trust the price of public debt to remain at the value $\beta$ that is needed to support an optimum allocation of resources in the private sector? As a start, we endow the fiscal authority with a policy rule that connects taxes (that is, the primary budget surplus) with the stock of maturing debt. The general form of this rule is

$$
\tau_{t}=T\left(B_{t}\right)
$$

where the function $T$ maps the public debt interval $[0,1+\alpha]$ into the feasible tax interval $[0, \bar{\tau}]$. Assuming that high-income households purchase the entire stock of public debt, equilibria again satisfy two budget constraints (one for the high-income household and another for the low-income household):

$$
\begin{gathered}
c_{t}^{H}=1+\alpha-\tau_{t}-q_{t} B_{t+1}, \\
c_{t+1}^{L}=1-\alpha+B_{t+1} ;
\end{gathered}
$$

one first-order condition for the high-income household (the other household chooses a corner solution):

$$
q_{t} u^{\prime}\left(c_{t}^{H}\right)=\beta u^{\prime}\left(c_{t+1}^{L}\right)
$$

and the government budget constraint:

$$
\tau_{t}+q_{t} B_{t+1}=B_{t}
$$

Combining equations (17) through (19) gives a simple first-order law of motion for the debt sequence $\left(B_{t}\right)$, which is

$$
\left[B_{t}-T\left(B_{t}\right)\right] u^{\prime}\left(1+\alpha-B_{t}\right)=\beta B_{t+1} u^{\prime}\left(1-\alpha+B_{t+1}\right) .
$$

If the household's intertemporal elasticity of substitution (IES) is not too low, we can solve equation (20) explicitly for $B_{t+1}$ to obtain

$$
B_{t+1}=G\left(B_{t} ; T\right) \text {. }
$$

Equation (21) says that the properties of the law of motion $G$ depend on the shape of the policy rule $T$. Fiscal policy can influence expectations by choosing the "right" policy rule. 


\section{Figure 1}

\section{Bubble Management}

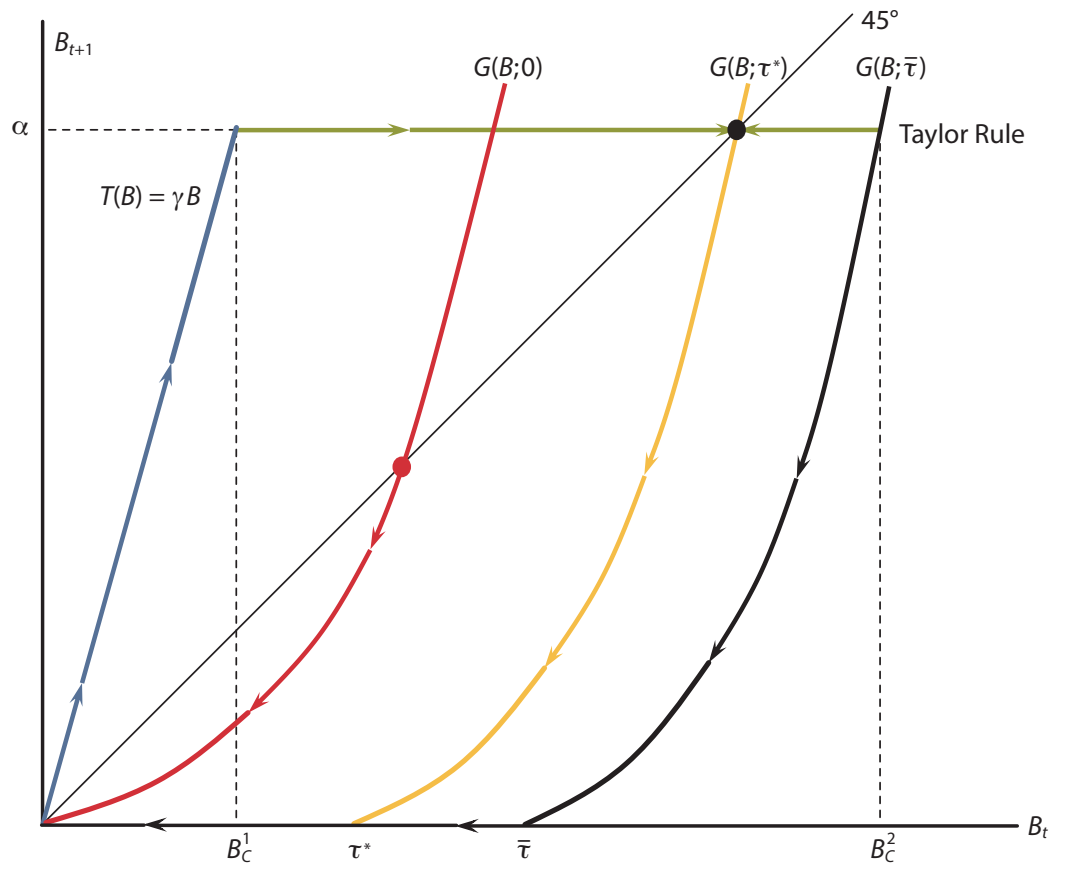

For each policy rule $T(B)$, an equilibrium is a nonnegative solution sequence $\left(B_{t}\right)$ to equation (20). Figure 1 describes some of the more interesting equilibria. To compare those with a no-bubble or no-liquidity outcome, we define the autarky yield

$$
\bar{R}=\frac{u^{\prime}(1+\alpha)}{\beta u^{\prime}(1-\alpha)},
$$

which is the reciprocal of the implied security price $\bar{q}$ when all credit markets are closed.

\section{Passive Policies}

Passive policies keep taxes constant for any value of public debt. Figure 1 shows how these policies fail. Keeping the $\operatorname{tax} T(B)$ constant anywhere in the interval $[0, \bar{\tau}]$, even if we choose the optimal value $\tau^{*}=\alpha(1-\beta)$, leaves the value $B$ of debt indeterminate in the interval $[0, \alpha]$ and thus open to shocks in expectations. The price of debt is also indeterminate in the interval $[\beta, 1 / \bar{R}]$. Equilibria are indeterminate under the red law of motion in Figure 1, the black law of motion in the same figure, and anything in between.

The red law describes the bubble dynamics of an overlapping-generations economy analyzed by Tirole (1985) and many others. It has the shape of a "reflected" offer curve-that is, the mirror image, relative to the vertical axis, of an offer curve for a two-period-lived house- 
hold with life cycle endowment $(1+\alpha, 1-\alpha)$. Offer curves are monotone if the IES is high enough to make current and future consumption gross substitutes, but can bend backward for low IES values. Bubble equilibria of this type exist if the no-bubble allocation is dynamically inefficient-that is, if

$$
\bar{R}<1
$$

It is worthwhile to reiterate here the argument by Farhi and Tirole (2012, p. 692) that "dynamic inefficiency is a sufficient but not necessary condition for the possibility of bubbles." Figure 1 clearly shows that public debt can command a positive price in a dynamically efficient but illiquid economy, as shown by the black and yellow laws of motion depicted in Figure 1. Under those laws, there is private demand for public debt, but it remains fragile and sensitive to adverse expectations.

\section{The Optimal Taylor Rule}

How do we keep the price of debt unchanged at the value $q=\beta$, which corresponds to the socially desirable allocation,

$$
\left(c_{t}^{H}, c_{t}^{L}\right)=(1,1)
$$

for all time? Equation (20) suggests a tax policy that will deliver tomorrow the optimum amount of liquidity $B^{*}=\alpha$ for any value $B_{t}$ today that is sufficiently close to the optimum liquidity $B^{*}$.

The literature on equilibrium selection ${ }^{4}$ provides some guidance on how to proceed. The key idea is to put $B_{t+1}=\alpha$ in equation (20) and solve for $T(B)$ - that is, to choose the policy rule:

$$
T(B)=B-\frac{\alpha \beta u^{\prime}(1)}{u^{\prime}(1+\alpha-B)} .
$$

Under this policy, the law of motion $G$ becomes the horizontal green line in Figure 1. For example, in the neighborhood of $\left(T\left(B^{*}\right), B^{*}\right)=(\alpha(1-\beta), \alpha)$, equation (23) takes the linear form of Taylor rules:

$$
T(B)-\tau^{*}=(1+\lambda)\left(B-B^{*}\right),
$$

where

$$
\lambda:=\alpha \beta \gamma
$$

and

$$
\gamma:=-u^{\prime \prime}(1) / u^{\prime}(1)
$$

The parameter $\lambda$ depends on the amplitude of income shocks and on the reciprocal of the IES. 
More generally, the nonlinear policy rule in equation (23) always keeps the public debt at the right value by raising taxes whenever public debt exceeds the target value $\alpha$ and lowering taxes in the reverse event. Liquidity is maintained at its socially desirable value $B^{*}$ by manipulating primary budget surpluses or, equivalently, taxes on buyers of public debt. These taxes exert an income effect on the private demand for public debt. When debt exceeds $B^{*}$, for example, taxes increase more than proportionally to contain the burgeoning demand for liquidity and future consumption. Overreactions to public debt movements are particularly appropriate when the income effect is small because investors are wealthy (high value of the parameter $\alpha$ ) or when the propensity to save out of income is relatively insensitive (large value of $\beta$ or low IES).

Any change in taxes will also feed into the bond price $q$ and the interest rate $r$, which satisfies

$$
1 / q=1+r
$$

In particular, tax increases on high-income investors at time $t$ will raise their income growth from $t$ to $t+1$, reduce liquidity demand, and exert upward pressure on yields. Policy rules such as equation (23) then can be expressed in terms of real yields if we rewrite equation (20) in the form

$$
1+r_{t}=u^{\prime}\left(1+\alpha-B_{t}\right) /\left[\alpha \beta u^{\prime}(1)\right]
$$

with $B_{t+1}$ set to equal its optimum value $\alpha$. Expanding $\left(r_{t}, B_{t}\right)$ about the optimal value $(1 / \beta-1, \alpha)$ we obtain a linearized interest rate rule that is completely equivalent to equation (24) - that is,

$$
\frac{r_{t}-r^{*}}{r^{*}}=\frac{\gamma}{1-\beta}\left(B_{t}-B^{*}\right)
$$

The government raises yields to curb excessive demand for liquidity and lowers yields to prop up liquidity.

Since taxes cannot exceed the modest upper bound $\bar{\tau}$, we need to know the range over which the linear approximation (28) is really useful. Clearly, the Taylor rule applies if $T(B)$ is in the interval $[0, \bar{\tau}]$ - that is, whenever $B$ lies in the interval $\left[B_{C}^{1}, B_{C}^{2}\right]$ around the target value $B^{*}$, where

$$
B_{C}^{1}:=B^{*}-\frac{\tau^{*}}{1+\lambda}<B_{C}^{2}:=B^{*}+\frac{\bar{\tau}-\tau^{*}}{1+\lambda} .
$$

If public debt falls below $B_{C}^{1}$, a linear tax rule with a sufficiently strong reaction coefficient will prevent the bubble from bursting, as shown in the blue law of motion in Figure 1. When the economy is dynamically inefficient, this policy amounts to a negative tax on investorsthat is, on people with temporarily high incomes (type- 2 households in periods $t=0,2, \ldots$ and type- 1 households in periods $t=1,3, \ldots)$. This subsidy will boost investors' flagging demand for assets and help achieve an optimum allocation of resources. As shown earlier, dynamic 
efficiency is a sufficient but not necessary motive for the holding of public debt. Illiquidity turns out to be a sufficiently plausible motive for policy intervention even in dynamically efficient economies.

\section{CONCLUSION}

This article reviews what we know about public debt management in economies facing severe liquidity shortages. In these circumstances, public liabilities are a substitute for private ones, and the demand for public debt has little or nothing to do with the dynamic inefficiency conditions identified in Tirole (1985): low interest rates relative to growth rates.

Even as it provides needed liquidity, public debt remains a bubble whose price is sensitive to forecasts of its future value. Thoughtful fiscal policy in these circumstances must balance the liquidity needs of the private sector against adverse expectations of devalued debt. A good way to strike this balance is to tie private sector demand for new debt with the current value of maturing debt. The necessary link is provided through a Taylor rule for public debt that acts as an automatic stabilizer on investor demand for public debt. It raises taxes on investors whenever debt exceeds the socially optimal amount of liquidity and lowers taxes in the reverse situation. The extent to which taxes should overreact to debt depends on structural parameters, notably the amplitude of income fluctuations and the intertemporal elasticity of substitution.

It is worth noting that fiscal policy is most successful in providing the optimum amount of liquidity when public debt and private debt are perfect substitutes, as we have assumed throughout this article. It would be interesting to see how this rule would work in an environment with uninsurable idiosyncratic income uncertainty in which public debt must replace not just one missing credit market but as many markets as there are idiosyncratic income states.

A related and perhaps weightier issue is averting financial distress in the first place. Liquidity provision seems to be the flip side of last-resort lending. ${ }^{5}$ It seems natural to design policies that would pursue both goals simultaneously.

\section{NOTES}

1 A typical modern example is Farhi and Tirole (2012), who analyze how "outside liquidity" complements private liquidity for financially constrained firms. Non-liquidity aspects of public debt include tax smoothing (Barro, 1979) and improving intertemporal allocations in life cycle economies (Auerbach and Kotlikoff, 1987).

2 This simple deterministic endowment process is the degenerate case of a stochastic economy with two Markovian states and a zero probability of remaining in the same state. Markovian endowments with two states are a straightforward extension.

3 Martin (2006), Ennis and Keister (2010), and Humphrey (2010) discuss policies that prevent large reductions in privately issued liquidity.

4 See Antinolfi, Azariadis, and Bullard (2007) and Pintus (2008) for recent examples of this procedure applied to monetary policy. Earlier examples include Grandmont (1986) and Woodford (1986).

5 See Bordo (1989) for an insightful historical review of last-resort lending. 


\section{Azariadis}

\section{REFERENCES}

Alvarez, Fernando and Jermann, Urban J. "Efficiency, Equilibrium, and Asset Pricing with Risk of Default." Econometrica, July 2000, 68(4), pp. 775-97; http://dx.doi.org/10.1111/1468-0262.00137.

Antinolfi, Gaetano; Azariadis, Costas and Bullard, James. "Monetary Policy as Equilibrium Selection." Federal Reserve Bank of St. Louis Review, July/August 2007, 89(4), pp. 331-41; https://research.stlouisfed.org/publications/review/07/07/Antinolfi.pdf.

Auerbach, Alan J. and Kotlikoff, Laurence J. Dynamic Fiscal Policy. Cambridge, MA: Cambridge University Press, 1987.

Bagehot, Walter. Lombard Street: A Description of the Money Market. London: Henry S. King, 1873.

Barro, Robert J. "On the Determination of the Public Debt." Journal of Political Economy, October 1979, 87(5 Part 1), pp. 940-71; http://dx.doi.org/10.1086/260807.

Bernanke, Ben S. and Gertler, Mark. "Agency Costs, Net Worth, and Business Fluctuations." American Economic Review, March 1989, 79(1), pp. 14-31.

Bordo, Michael D. "The Lender of Last Resort: Some Historical Insights." NBER Working Paper No. 3011, National Bureau of Economic Research, June 1989; http://www.nber.org/papers/w3011.pdf.

Bulow, Jeremy and Rogoff, Kenneth. "Sovereign Debt: Is to Forgive to Forget?" American Economic Review, March 1989, 79(1), pp. 43-50.

Ennis, Huberto M. and Keister, Todd. "Banking Panics and Policy Responses." Journal of Monetary Economics, May 2010, 57(4), pp. 404-19; http://dx.doi.org/10.1016/j.jmoneco.2010.04.005.

Farhi, Emmanuel and Tirole, Jean. "Bubbly Liquidity." Review of Economic Studies, April 2012, 79(2), pp. 678-706; http://dx.doi.org/10.1093/restud/rdr039.

Grandmont, Jean-Michel. "Stabilizing Competitive Business Cycles." Journal of Economic Theory, October 1986, 40(1), pp. 57-76; http://dx.doi.org/10.1016/0022-0531(86)90007-4

Hellwig, Christian and Lorenzoni, Guido. "Bubbles and Self-Enforcing Debt." Econometrica, July 2009, 77(4), pp. 113764; http://dx.doi.org/10.3982/ECTA6754.

Humphrey, Thomas M. "Lender of Last Resort: What It Is, Whence It Came, and Why the Fed Isn't It." Cato Journal, Spring/Summer 2010, 30(2), pp. 333-64.

Kehoe, Timothy J. and Levine, David K. "Debt-Constrained Asset Markets." Review of Economic Studies, 1993, 60(4), pp. 865-88; http://dx.doi.org/10.2307/2298103.

Kiyotaki, Nobuhiro and Moore, John. "Credit Cycles," Journal of Political Economy, April 1997, 105(2), pp. 211-48; http://dx.doi.org/10.1086/262072.

Kocherlakota, Narayana R. "Bursting Bubbles: Consequences and Cures." Presented at the Macroeconomic and Policy Challenges Following Financial Meltdowns Conference, International Monetary Fund, Washington, DC, April 3, 2009; https://www.imf.org/external/np/seminars/eng/2009/macro/pdf/nk.pdf.

Martin, Antoine. "Liquidity Provision vs. Deposit Insurance: Preventing Bank Panics without Moral Hazard." Economic Theory, May 2006, 28(1), pp. 197-211; http://dx.doi.org/10.1007/s00199-005-0613-x.

Pintus, Patrick A. "Laffer Traps and Monetary Policy." Federal Reserve Bank of St. Louis Review, May/June 2008, 90(3 Part 1), pp. 165-74; https://research.stlouisfed.org/publications/review/08/05/Pintus.pdf.

Thornton, Henry. An Enquiry into the Nature and Effects of the Paper Credit of Great Britain. London: J. Hatchard, 1802.

Tirole, Jean. "Asset Bubbles and Overlapping Generations." Econometrica, November 1985, 53(5), pp. 1499-528; http://dx.doi.org/10.2307/1913232.

Woodford, Michael. "Stationary Sunspot Equilibria in a Finance Constrained Economy." Journal of Economic Theory, October 1986, 40(1), pp. 128-37; http://dx.doi.org/10.1016/0022-0531(86)90011-6. 